\title{
EVALUATION OF FETAL LUNG MATURITY BY TURBIDITY TESTING AND TAP TEST
}

\author{
Bulent KARS $^{1}$, Ayse Yasemin Karageyim KARSIDAG ${ }^{1}$, Esra Esim BUYUKBAYRAK ${ }^{1}$, Berrin TELATAR ${ }^{2}$, Cem TURAN $^{1}$, \\ Orhan UNAL ${ }^{1}$
}

${ }^{1}$ Department of Obstetrics and Gynecology, Dr. Lutfi Kirdar Education and Research Hospital, Kartal, Istanbul, Turkey
${ }^{2}$ Department of Pediatrics Clinic, Dr. Lutfi Kirdar Education and Research Hospital, Kartal, Istanbul, Turkey

\section{SUMMARY}

Aim: In this study our aim was to predict the fetal lung maturity with bedside tests which do not not require special technology and to find out their routine applicability.

Material and Methods: Fifty six patients were recruited into the study and samples were collected from patients that were delivered via cesarean or vaginal delivery for obstetric reasons. Tap test and turbidity tests were performed by the same physician at the bedside or in the operation theatre after the sample collection.

Findings: Respiratory distress syndrome was detected in 12 newborn out of $56(\% 21,4)$. For tap test the sensitivity was $\% 91$ and spesificity was \%88; whereas sensitivity was $\% 83$ and spesificity was $\% 65$ for turbidity test. Result: We think that Tap test and turbidity test for the detection of fetal lung maturity as a bedside test are helpfull if other fetal lung maturity tests are not technologically available.

Key words: fetal lung maturity, tap test, turbidity test

Journal of Turkish Society of Obstetrics and Gynecology, (J Turk Soc Obstet Gynecol), 2011; Vol: 8 Issue: 1 Pages: 25 - 31

\section{ÖZET}

\section{FETAL AKCIĞER OLGUNLUĞUNUN BULANIKLIK TESTİ VE TAP TESTI KULLANARAK BELIRLENMESI}

Amaç: Akciğer olgunluğunu tespit etmek amacıyla özel teknoloji gerektirmeyen basit bazı testleri karşılaştırmak ve rutinde kullanilabilirliğini değerlendirmek.

Gereç ve yöntemler: Obstetrik nedenler ile doğumu başlayan, 30-41 hafta arası gebelerden normal doğum travayı veya sezaryen sırasında amnion sıvısı örneği alınan 56 hasta çalışmaya dahil edildi. Örneğin alınmasını takiben hasta başında aynı kişi tarafindan Tap test ve Turbidite(bulanıklık) testi yapıldı.

Bulgular: Yenidoğanların 12 'sinde (\% 21,4) respiratuar distres sendromu (RDS) gelişirken, diğerlerinde RDS gelişmedi. Tap testi ile akciğer matürite tespiti için sensitivite \% 91, spesifite \% 88; bulanıklı testi ile akciğer matürite tespiti için sensitivite \% 83, spesifisite \% 65 olarak tespit edildi.

Sonuç: Tap testi öncelikli olmak üzere, bulanıklık testi ise ikinci seçenek olarak teknolojik imkânlar sınırlı ise hasta başında hızlı karar vermede yardımcı olabilir.

Anahtar kelimeler: akciğer olgunluğu, tap testi, turbidite testi

Türk Jinekoloji ve Obstetrik Derneği Dergisi, (J Turk Soc Obstet Gynecol), 2011; Cilt: 8 Sayl: 1 Sayfa: 25- 31

Address for Correspondence: Uzm. Dr. Bülent Kars. Milangaz cad. Ünlüer sitesi C Blok D: 23 Esentepe Kartal, İstanbul, Turkey Phone: +90 (216) 4574741

e-mail: bulent1972kars@yahoo.com

Received: 14 January 2010, revised: 09 July 2010, accepted: 09 August 2010, online publication: 15 December 2010 


\section{INTRODUCTION}

During the various pregnancy complications early assessment of fetal lung maturity and for the cases that have not completed lung maturity delay or suspension of delivery with various pharmacological methods, prevention of iatrogenic prematurity especially by reducing elective cesarean operations, use of steroids in order to accelerate lung maturity, methods such as use of respirators during the neonatal period and surfactant therapy during the neonatal period have provided a substantial decrease in neonatal mortality and morbidity. The effective ways to prevent problems that a premature baby might face due to preterm labor are prevention of preterm labor if possible, accelerate lung maturity in cases when intervention is needed the ability to correctly recognize the presence of fetal lung maturity.

The relationship between death due to respiratory difficulties in newborn infants and hyaline membranes was first described at the beginning of $20^{\text {th }}$ century, by Von Neergaard ${ }^{(1)}$. In this study air-liquid transfer of the lungs was noted. From that time until the early 1960s, the relationship between lack of maturity of lungs and respiratory difficulty made no progress until Pattle $^{(2)}$ and Clements ${ }^{(3)}$ showed showed the presence of surfactant in the lung tissues. Avery and $\mathrm{Mead}^{(4)}$ have found reduced surfactant levels in patients with respiratory failure in their study with newborns that were diagnosed with Respiratory Distress Syndrome (RDS).

Even though respiratory distress syndrome (RDS) or hyaline membrane disease have been used as synonyms in the obstetric literature, RDS is a clinical syndrome that might arise from several cardiopulmonary disorders. Hyaline membrane disease, on the other hand, is a specific type of RDS that causes characteristic pathological findings in the autopsy and arises from inadequate production of surfactant $(5)$.

Once the relationship between decrease in surfactant levels and hyaline membrane, studies have focused on ways to increase and improve the synthesis of surfactant. The first positive development in this area was recorded by Gluck et $\mathrm{al}^{(6)}$ when they estimated lung maturity and the risk of developing RDS in preterm infants by determining the lecithin / sphingomyelin (L / S) ratio in amniotic fluid. In 1976, Hallman and colleagues have demonstrated that lung maturity could be determined effectively by the determination of fosfatidilgliserol in the amniotic fluid( ${ }^{(7)}$. Even though steroids were observed to increase lung maturity in the early 1960s, Liggins and Howie has shown for the first time in 1972 that maternal steroid treatment reduces the incidence of respiratory distress syndrome ${ }^{(8)}$. The most important development affecting the outcome of newborns in lung research was provided by showing the effectiveness of the use of surfactant in RDS and other lung diseases by Fujiwara and colleagues in 1980 (9).

Despite this rapid development in the areas of obstetrics and neonatalogy prematurity and related RDS and its complications are still the foremost reasons of neonatal mortality and morbidity.

For this purpose, a number of tests were developed in order to measure the different parts of surfactant that pass to the amniotic fluid after being produced in fetal lungs and targets to predict the fetal lung maturity in this way. Even though these tests have been used in clinical practice for many years, none of them are perfect and each one contains varying proportions of error. Furthermore, some of these tests are time consuming and expensive, and they require special technologies and trained personnel as well. Therefore, the need for tests that are cheap, easy to be done, result in a short time, that do not require special technology or team, and have a high reliability is increasing. While studies and searches in this area are ongoing, in this study we have investigated the degree of accuracy of some tests used in the determination of fetal lung maturity. The objective of this study was to compare the results of some simple tests that do not require special technology and to determine whether they might be used in routine or not.

\section{MATERIALS AND METHODS}

This study which was performed in order to identify the affectivity of the two tests used in determination of lung maturation was completed in a 1-year period prospectively.

80 singleton pregnancies that cesarean delivery was performed because of obstetric causes and amniotic fluid was obtained during surgery and amniotic fluid sample taken during amniotomy during the normal labor were included in the study. While samples were 
acquired with amniotomy in twenty cases, in 60 cases amniotic fluid was taken during cesarean section. The process was explained and "received consent" principle was applied to each patient that sample was taken. Among the 80 amniotic fluid samples the ones that were contaminated with blood or meconium, cases that sufficient amounts of fluid for performing all the tests could not be taken, samples that belong to patients who did not labor in the first 72 hours after samples were taken and samples that belong to fetuses with cardiopulmonary anomaly or sepsis were excluded. At the end 56 cases that provide all the necessary criteria consisted the study group. Indications for delivery in the patients that consisted the study group is seen in Table I. Amniotic fluid samples provided from all the patients were immediately examined for fetal lung maturity. within a few minutes after the samples were taken hasta başında Tap test and turbidity test were performed by the same person.

Table I: Indications of birth in study cases.

\begin{tabular}{lr}
\hline Indication & N \\
\hline Preterm labor & 7 \\
Chronic Hypertension & 3 \\
Preeclampsia & 16 \\
Premature Rupture of Membrances & 2 \\
Diabetes Mellitus & 6 \\
Polihydramnios & 1 \\
Elective & 17 \\
Other & 4 \\
\hline
\end{tabular}

\section{Turbidity Test:}

After the amniotic fluid samples were taken into a 10 $\mathrm{ml}$ non-heparinated blood collection tube, the tubes were put in front of a page of a book written in bold and 14 points characters. If the writing in the background could be read through the amniotic fluid, the fluid was clear and the result was considered as immature in terms of lung maturity (Figure 1). If the text in the background could not be read, the amniotic fluid sample was blurred (turbid) and the result was considered as mature in terms of lung maturity (Figure 2). All assessments were performed by the same person, using the same light conditions and the same page.

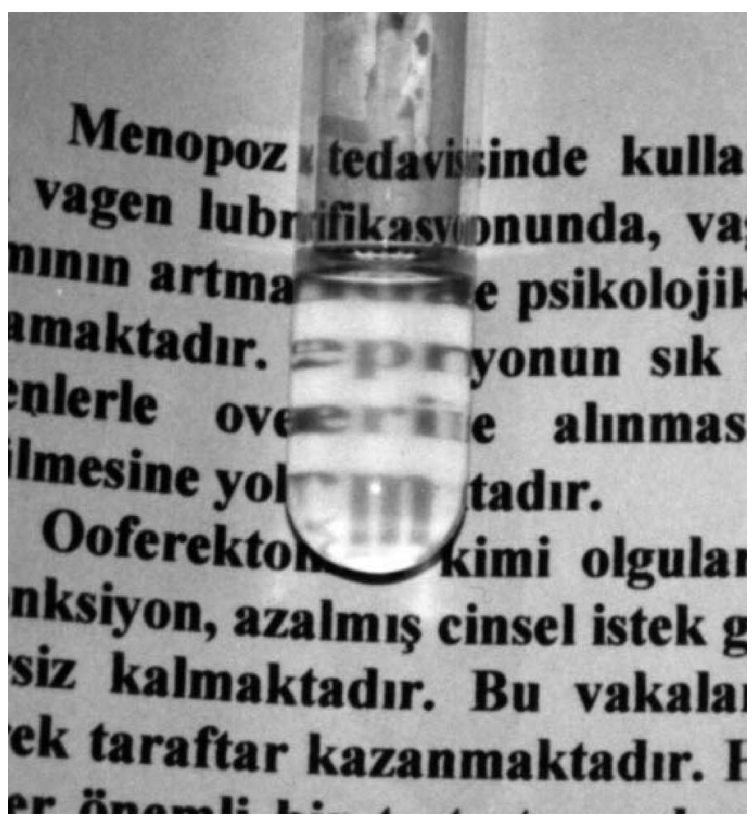

Picture 1: Reading an article written in "'d214 bold"' 33 characters through the amniotic fluid: Turbidity test immature.

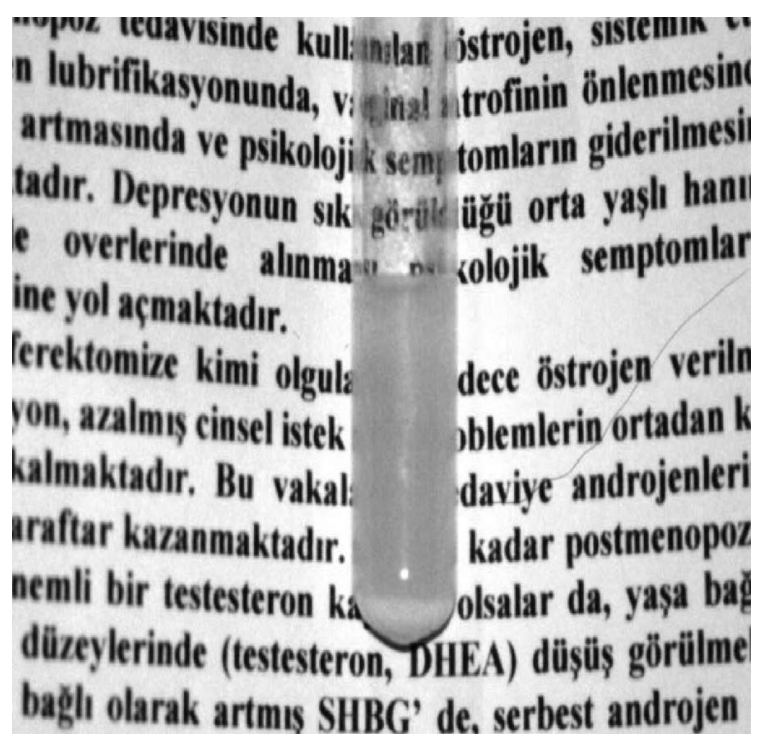

Picture 2: An unreadable article written in "'d214 bold"'d3 characters through the amniotic fluid: Turbidity test mature.

\section{Tap Test:}

This was performed as described by Socol and colleagues. $1 \mathrm{ml}$ of the amniotic fluid and 1 drop of $6 \mathrm{~N} \mathrm{HCl}$ were mixed in the blood collection tube and $1.5 \mathrm{ml}$ diethylether was added. While the tube was held with one hand, with the index finger of the other hand the tube was knocked by short and slit hits. In the ether layer 200-300 of bubbles were observed. At the second minute assessment the cut-off levels were set whether 5 bubbles were seen or not. If in the ether layer less than 5 bubbles were seen the result was considered as mature in terms of lung maturity (Figure 3), and if the number of foams were 
five or more the results were evaluated as immature (Figure 4). All the readings were performed by the same person.

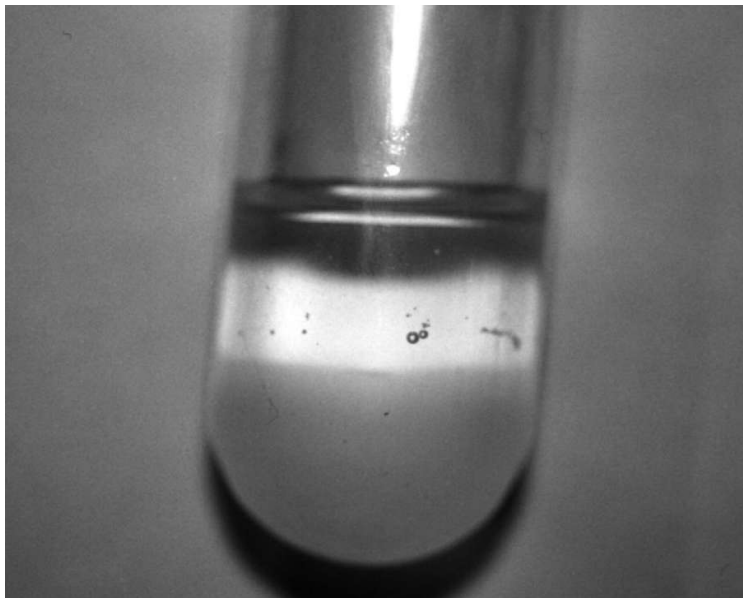

Picture 3: Tap test in amniotic fluid (There are less than 5 bubbles). The result is mature.

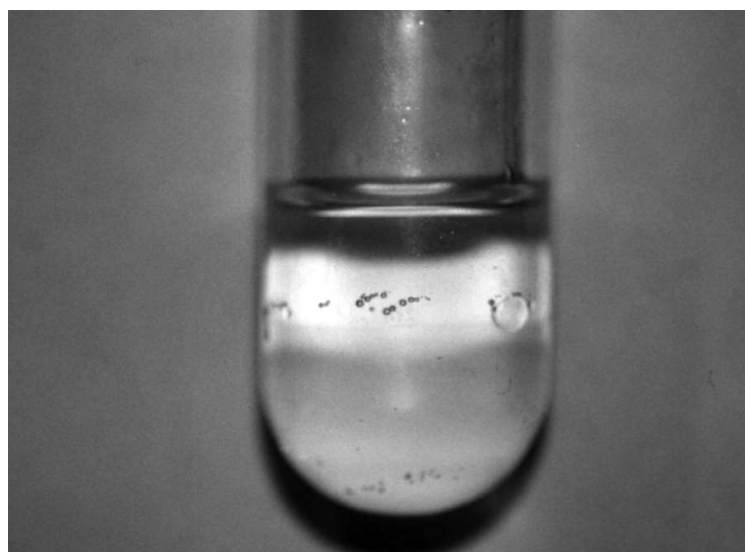

Picture 4: Tap test in amniotic fluid (There are more than 5 bubbles).

The result is immature.

In all patients, gestational age was determined according to the last menstrual period and ultrasound measurements. All infants were evaluated in the neonatology ward following the birth. The neonatolog performing the assessment was unaware of the results of fetal lung maturation tests and the existence of the following findings was considered as RDS:

1. Groaning, tachypnea, retraction, and clinical signs such as cyanosis that start within 6-8 hours after the birth.

2. Oxygen requirement that lasts more than 24 hours.

3. arterial blood gas analysis showing oxygen partial pressure of less than $50 \mathrm{~mm} \mathrm{Hg}$.

4. Chest X-ray findings consistent with RDS.

5. Negative blood culture results.
Newborns that require oxygen for a period of less than 24 hours after birth and do not have typical chest Xray findings were defined as transient tachypnea of the newborn (RDS II) and were not included in the RDS group.

All the laboratory results Obtained were evaluated according to the presence of RDS in the newborn and their affectivity was investigated by comparison with each other. After the records and results of all patients were collected on the computer descriptive and analytical statistics were performed using the SPSS 9.0 (Statistical Package for Social Science 9.0) package program. The sensitivity, specificity, positive predictive value (PPV), negative predictive value (NPV) and efficiency was investigated appropriately.

\section{RESULTS}

Among the 56 amniotic fluid samples evaluated 11 of them were taken durimg normal birth at the time of amniotomy, and 45 of them were taken during cesarean section. Gestational period of the patients ranged between $30-41$ weeks, and 33 of the patients (58.9\%) were before 37 weeks of gestation and considered as preterm. While in 12 of the newborns (21.4\%) RDS was developed, transient tachypnea of the newborn infants was seen in 3 and these babies were included in the non-RDS group. The Distribution of the patients according to gestational week is shown in Table II, the distribution of newborns that developed or did not develop RDS according to their gestational week and birth weight appears in Table III.

Table II: Gestational weeks of the study cases

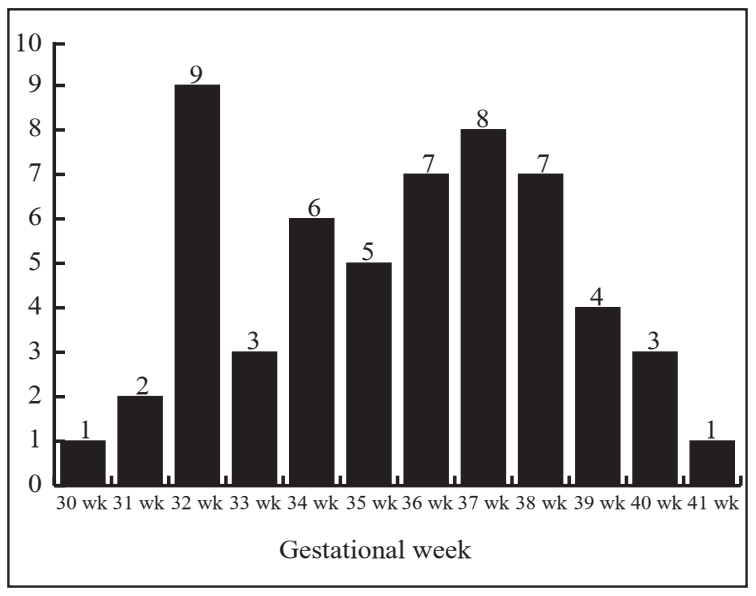


When the gestational week of 56 pregnants in our study was examined, the average gestational age in the newborns that did not develop RDS was found as 36.50 \pm 2.20 , and when the gestatioanl week of 12 newborns that developed RDS were examined the average gestational week was $31.91 \pm 0.99$. The advanced gestational week in newborns without RDS was statistically significant compared to newborns that developed RDS $(p=0.0001)$.

Table III: Distribution of newborns that developed or did not develop RDS according to their gestational ages and birth weights.

\begin{tabular}{|c|c|c|c|c|}
\hline & $\mathbf{N}$ & $\begin{array}{l}\text { Average } \pm \\
\text { standard } \\
\text { deviation }\end{array}$ & aralık & $\mathbf{P}$ \\
\hline Gestational week & 56 & $35,51 \pm 2,75$ & $30-41$ & \\
\hline RDS exist & 12 & $31,91 \pm 0,99$ & $30-34$ & \\
\hline RDS does not exist & 44 & $36,50 \pm 2,20$ & $32-41$ & $0,0001 *$ \\
\hline Brith wieght (gr.) & 56 & $2738,21 \pm 0,917$ & $1180-4950$ & \\
\hline RDS exist & 12 & $1692,50 \pm 0,408$ & $1180-2700$ & \\
\hline RDS does not exist & 44 & $3023,40 \pm 0,804$ & $1700-4950$ & $0,0001 *$ \\
\hline
\end{tabular}

When the birth weight of 56 newborns in our study was examined, the birth weight of newborns without RDS were $3023.40 \pm 0.804$, while the birth weight of 12 newborns that developed RDS was reported as $1692,50 \pm 0,408$. The difference in birth weight of newborns without RDS was statistically significant compared to newborns that developed RDS ( $\mathrm{p}=$ 0.0001).

The sensitivity, specificity, the effectivity with positive predictive value (PPV) and negative predictive values (NPV) obtained separately for tap test and turbidity test are shown in Table IV.

Table IV: Statistical results for Tap test and Turbidity test.

\begin{tabular}{llllll}
\hline & $\begin{array}{l}\text { Sensitivity } \\
\text { \% }\end{array}$ & $\begin{array}{l}\text { Specificity } \\
\text { \% }\end{array}$ & $\begin{array}{l}\text { PPV } \\
\mathbf{\%}\end{array}$ & $\begin{array}{l}\text { NPV } \\
\mathbf{\%}\end{array}$ & $\begin{array}{l}\text { Efficiency } \\
\%\end{array}$ \\
\hline $\begin{array}{l}\text { Tap test } \\
\text { Turbidity } \\
\text { test }\end{array}$ & 91 & 88 & 68 & 97,5 & 89 \\
\hline
\end{tabular}

In our study the sensitivity for tap test for immaturity was $91 \%$, specificity was $88 \%$, PPV was $68 \%$, and NPV was $97.5 \%$. for the results of turbidity test these values have been evaluated as $83 \%, 65 \%, 40 \%$ and $63 \%$, respectively.

\section{DISCUSSION}

All the tests used for determination of lung maturity are based on detection of surfactant and various compounds in the structure of surfactant. The test that would be used for this purpose should be simple to do, economic, intra-and inter-laboratory variability should be low, reproducible, and should hae a high reliability in determination of RDS. Today, the determination of $\mathrm{L}$ / $\mathrm{S}$ ratio and determination of fosfatidilgliserol are the tests used as "gold standard". While these tests have high predictive values for results as mature, for immature results they have lower predictive values $(7,10-13)$. In addition, these tests are time consuming, expensive, requires technology and trained personnel. Therefore, today there is no test accepted as ideal.

Tap testing was first identified in 1984 by Socol and his colleagues which is a simple and inexpensive test (14). Afterwards the evaluation of 332 amniotic fluid samples performed by the same authors clarified that 5 th minute sensitivity of Tap test was $90.9 \%$, specificity was $87.4 \%$, PPV was $63.5 \%$, and NPV was $97.6 \%{ }^{(15)}$. In another study comparing the Tap test and profile of phospholipids 5 th minute sensitivity was found $90.9 \%$, specificity $91.8 \%$, PPV 50\%, NPV was $99.1 \%(16)$. In the evaluation of 5th minute we found that 'Tap test' has a sensitivity of $91 \%$, specificity $88 \%$, PPV $68 \%$, and NPV $97.5 \%$.

Vernix caseosa is an oily complex material that is seen on fetal skin during the $3 \mathrm{rd}$ trimester of pregnancy and consists of epithelial residuals. As the pregnancy progresses and epidermis becomes mature, the amount of squalene in the vernix increases compared to cholesterol which in turn decreases the adhesion of the vernix to the fetal skin(17). Thus, by separation of vernix from the fetal skin and passage into the amniotic fluid the number of particles free-floating in the amniotic fluid increases. Therefore, the turbidity of amniotic fluid increases.

It has been reported that increased turbidity of the amniotic fluid with the progression of pregnancy could be used in determination of fetal lung maturation and this is correlated with the results of $\mathrm{L} / \mathrm{S}^{(18-20)}$.

Di Giovanni and Parsons ${ }^{(18)}$ have shown in 17 diabetic patients that in all samples of fuzzy amniotic fluid $\mathrm{L}$ / S ratio was greater than 2 and phosphatidylglyserol was identified in all of them. Hastwell(19) has reported that in 35 pregnant women with fuzzy amniotic fluid 
$\mathrm{L} / \mathrm{S}$ ratio was greater than 2 . Strong et al ${ }^{(20)}$ showed that 29 out of $30(97 \%)$ patients with fuzzy amniotic fluid L / S ratio was mature and it was immature in only 1 patient, on the contrary they showed that 50 out of $70(71 \%)$ patients with a clear amniotic fluid L / S ratio was smaller than 2 , and in 20 of them it was greater. In another study with this test Sbarra et al.(21). stated that the test can be easily applied by anyone without experience. 94 amniotic fluid that is known as positive (mature) and negative (immature) was evaluated by technicians and experienced clinicians, and at the end observed a high compliance (87.2\%). In this study, sensitivity was $90.8 \%$ and specificity was $70.3 \%$. In a recent study in the literature using this test Adair et al.(22) combined this test with fluorescence polarization test and detected 89 from the 97 cases $(91.2 \%)$ that Fetal Lung Maturity (TDx FLM) was $<70 \mathrm{mg} /$ day. In this study PPV was found 91\%, and NPV was $87 \%$.

In our study, we compared amniotic fluid turbidity with the results of neonatal RDS. We have determined sensitivity as $83 \%$, specificity $65 \%$, PPV $40 \%$ and NPV 63\%. We have found that these results are quite lower than the Tap test values or results from studies of other researchers. We believe that the priority given to the tap test, both tests could be chosen when technological capabilities are not enough or other tests are unavailable.

We should not forget that assessment of fetal lung maturation is one of the most important steps while deciding in birth of the fetus. The objective should be protection of the fetus from risks such as sequelae of RDS, necrotizing enterocolitis, intraventricular hemorrhage, patent ductus arteriozus and neonatal sepsis as much as possible. However, the main point in deciding birth is the clinical condition of the mother and the fetus.

\section{REFERENCES}

1. Von Neergaard: Neue Auffassungen uber einen Grundbegriff der aterr mechanik. Z Gesamte Exp Med 1929; 66: 373.

2. Pattle RE: Properties, function and origin of the alveolar lining layer. Nature 1955; 175: 1125

3. Clements JA : Surface tension of lung extracts . Proc Soc Exp Biol Med 1961; 95: 170

4. Avery ME, Mead J: Surface proteins in relation to atelectasis and hyaline membrane disease. Am J Dis Child 1959; 97: 517.

5. Weiner SA, Weinstein L: Fetal Pulmonary Maturity and Antenatal Diagnosis of Respiratory Distress Syndrome. Obstet and Gynecol Survey 1987 ; 40: 75- 81 .

6. Gluck L, Kulovich MV, Boerer RC Jr, et al: Diagnosis of respiratory distress syndrome by amniocentesis. AM J Obstet Gynecol 1971; 109: 440- 5.

7. Halmann M, Kulovich M, Kirkpatrick E, et al: Phosphatidylinositol and phosphatidylglyserol in amniotic fluid: Indices of lung maturity. AM J Obstet Gynecol 1976; 125: 613- 7.

8. Liggins GC, Howie RN: A controlled trial of antepartum glucocorticoid treatment for prevention of the respiratory distress syndrome in prematıre infants. Pediatrics 1972; 50: 515.

9. Fujiwara $\mathrm{T}$, Maeta $\mathrm{H}$, Chida $\mathrm{S}$, et al: Artificial surfactant therapy in hyaline membrane disease. Lancet 1980; 1: 55.

10. Kulovich MV, Gluck L. The lung profile: Complicated pregnancy. AM J. Obstet Gynecol 1975; 135: 64- 9 .

11. Peipert JF, Sweeney PJ: Diagnostic testing in Obstetric and Gynecology: A Clinician' s guide. Obstet Gynecol 1993; 82: 619- 23.

12. Borer J. RC, Gluck L, Freemen RK, et al: Prenatal prediction of the respiratory distress syndrome. Pediatr Res 1971; 5: 65560.

13. Tsai MY, Shutz EK, Williams PP, et al: Assay of disaturated phosphatidylcholine in amniotic fluid as a test of the fetal lung maturity: Experience with 2000 analyses; Clin Chem 1987; 33B 1648- 51.

14. Socol ML, Sing E, Depp OR: The Tap test: a rapid indicator of fetal pulmonary maturity AM J Obstet Gvnecol 1984; 148 : B 445- 50 .

15. Socol ML: The tap test: Confirmation of a simple, rapid, inexpensive, and reliable indicator of fetal pulmonary maturity. AM J Obstet Gynecol 1990; 162: 218- 22.

16. Kassanos D, Batsis D, Gregoriou 0, Bezontakos Ch, Kontogeorgi Z, Zourlas PA: The tap test: A simple and inexpensive method for the diagnosis of fetal pulmonary maturity. INT J Gynecol Obstet $1993 ; 41: 135-8$.

17. Hill LM, Breckle R: Vernix in amniotic fluid: sonographic detection. Radiology 1986; 158: 80- 3.

18. Di Giovanni LM, Porsans MT: Predictive value of vernix for fetal maturity. Soc Perinat Obstet Abstracts 1988; 1446.

19. Hastwell G: Amniotic fluid: Visual assessment of fetal maturity. Lancet 1975; L 349- 54

20. Strong Jr TH, Hayes AS, Sawyer AT, et al: Amniotic fluid turbidity: A useful adjunct for assessing fetal pulmonary maturity status. Int J Gynecol Obstet 1992; 38: 97- 100.

21. Sbarra AJ, Chaudhury A, Cetrulo CL, et al; A rapid visual 
test for predicting fetal lung maturity, Am J Obstet Gynecol 1991; 165(1): 1351- 3.

22. Adair CD, Sanches-Ramos L, McDyer DL, et al; Predicting fetal lung maturity by visual assessment of amniotic fluid turbidity: Comparison with fluorescence polarization assay; South Med J 1995; 88: 1031- 3 . 